\title{
THE NON-INCLUSIVE NATURE OF THE "HOUSE WITH ÇARDAK" TYPOLOGY IN THE ALBANIAN CONTEMPORARY URBAN CONTEXT: CASE STUDY BERAT CITY
}

\author{
Ani Çuedari ${ }^{1^{*}}$ \\ ${ }^{1 *}$ Polytechnic University of Tirana, Faculty of Architecture and Urbanism, Tirana, Albania; \\ *Corresponding Author Ani Çuedari, e-mail: anicuedari@outlook.com;
}

Received April 2021; Accepted May 2021; Published June 2021;

DOI: https://doi.org/10.31407/ijees11.333

\begin{abstract}
The purpose of this paper is to introduce, understand and analyze the traditional houses with "çardak", focusing particularly in the evolution of this typology in sloping terrains; such as that of Berat city and its invocation in nowadays housing solutions. This work aims to introduce thehouse with "çardak" and its evolution in time: find out the main architectonic charasteristic elements, the distinct morphology of this house, in order to understand it in a formal, functional and structural level; and to reinterpretate the house with "çardak": using thetraditional elements of this habitat and speaking their language in the contemporary modern houses of the Albanian urban context, addressing a ew problematic such as accessibility to this typology. The expected results are: finding out a new applicative methodology of "çardak" reinterpretation; drawing attention to these native (historical) buildings, as the most appropriatechoices for some special Albanian situations, urban and climatic conditions; bring a methodological contribution to the reflection of local tradition, to the maintainance and spreading of local identity through vernacular architecture, according to the local needs. Interventions for accessibility can decline the house from its typology; as the terrain make it really hard to implement solutions like ramps and elevators, in order to preserve its morpologhy and geometry. The underlined conclusion of this work is that the reinterpretation of the built and vernacular heritage of the past, is really important in preserving local identity and adjusting to the differences of aesthetic and functional demands of our contemporary way of building.
\end{abstract}

Keywords: Çardak, Typology Reinterpreatation, inclusive, non-inclusive, Local Identity, Morphology, Vernacular Architecture, accessibility. 